\title{
MOTIVASI BELAJAR SISWA PADA MATA PELAJARAN PEMELIHARAAN SISTEM KELISTRIKAN KENDARAAN RINGAN
}

\author{
Muhammad J. Dinata ${ }^{1}$, Inu H. Kusumah ${ }^{2}$ \\ Universitas Pendidikan Indonesia \\ Jl. Dr. Setiabudhi No. 229, Bandung 40154 \\ m.j.dinata@gmail.com
}

\begin{abstract}
ABSTRAK
Tujuan penelitian ini yaitu untuk mengetahui motivasi siswa pada pembelajaran sistem kelistrikan kendaraan ringan. Metode Penelitian ini menggunakan metode penelitian deskriptif. Instrumen yang digunakan pada penelitian ini berupa angket. Penelitian ini dilaksanakan di kelas XI Teknik Kendaraan Ringan SMK Negeri 6 Bandung tahun pembelajaran 2016/2017. Skala pengukuran pada penelitian ini menggunakan skala pengukuran Likert karena penelitian ini mengukur sikap, pendapat atau persepsi seseorang. Indikator-indikator pengukuran antara lain minat, kemandirian, kemauan, nilai ulangan, kepercayaan diri dalam belajar dan orientasi pada hasil. Hasil penelitian menunjukkan bahwa motivasi belajar siswa sebesar 94,6\%, termasuk katagori sangat tinggi. Kesimpulannya bahwa sebagian siswa memiliki motivasi belajar yang sangat tinggi pada mata pelajaran pemeliharaan sistem kelistrikan kendaraan ringan.
\end{abstract}

Kata kunci: motivasi, sistem kelistrikan, kendaraan ringan.

\section{PENDAHULUAN}

Jenjang pendidikan formal terdiri atas pendidikan dasar, pendidikan menengah, dan pendidikan tinggi. Pendidikan menengah atau Sekolah Menengah Kejuruan (SMK), merupakan salah satu dari jenjang pendidikan nasional sebagai lembaga pendidikan formal yang bergerak pada bidang kejuruan dan lulusannya harus bisa memasuki dunia usaha dan dunia industri. Tujuan sekolah bukan saja mencapai tujuan dari pendidikan nasional akan tetapi siswa juga memiliki kemampuan soft skill dan hard skill, untuk membekali siswa memiliki kemampuan soft skill dan hard skill siswa harus memiliki motivasi supaya mau berkerja keras dan ambisius agar dapat bersaing di dunia usaha dan dunia industri.

Ketercapaian keberhasilan, tidak mungkin tanpa di landasi dengan motivasi yang tinggi. Motivasi dapat dilihat dari sikap siswa yang ingin menggapai tujuannya. Guru harus membekali motivasi belajar kepada siswa supaya siswa dapat percaya diri dalam mengerjakan dan menyelesaikan semua tugas-tugas yang di berikan di sekolah. Motivasi merupakan dorongan yang terdapat dalam diri seseorang untuk berusaha mengadakan perubahan tingkah laku yang lebih baik dalam memenuhi kebutuhannya (Uno, 2009). Ada beberapa siswa sering izin keluar masuk kelas, sering ribut di kelas, ada beberapa siswa yang main HP pada saat

\footnotetext{
1 Mahasiswa Departemen Pendidikan Teknik Mesin FPTK, UPI

2 Dosen Departemen Pendidikan Teknik Mesin FPTK, UPI
} 
pelaksanaan belajar dan ada beberapa siswa yang sering tidak masuk kembali kekelas. Motivasi adalah merujuk pada proses dimana saran tingkah laku yang diarahkan, dirayu dan didukung (Schunk, 2012). Motivasi merupakan suatu proses pemberian energi secara langsung dan mengarahkan pada memelihara prilaku (Sanrock, 2011). Motivasi mengacu pada alasan ingin melakukannya dengan baik di sekolah dan telah diakui sebagai faktor penting yang mendorong belajar lebih baik dan prestasi.

\section{METODE PENELITIAN}

Metode yang digunakan yaitu metode penelitian deskriptif. Tempat pelaksanaan pada penelitian ini adalah Sekolah Menengah Kejuruan Negeri 6 Bandung, adalah siswa kelas XI TKR 5 dan XI TKR 6 yang berjumlah 74 siswa. Populasi dalam penelitian di SMK Negeri 6 Bandung ini adalah siswa kelas XI Teknik Kendaraan Ringan berjumlah 6 kelas, sedangkan Sampel pada penelitian ini adalah siswa kelas XI TKR 5 dan XI TKR 6 yang berjumlah 74 siswa, di karenakan kelas XI TKR 5 dan XI TKR 6 tiap tahun memilik permasalahan yang sama.

\section{HASIL PENELITIAN}

Hasil penelitian menunjukkan adanya perbedaan kondisi dilingkungan sekolah yang sangat berpengaruh terhadap motivasi belajar siswa. Perbedaannya dengan sekolah lain yaitu dimana siswa harus berpindah kelas setiap kali jam pelajaran selesai, dengan demikian siswa pada saat pergantian jam pelajaran ada beberapa siswa yang tidak mengikutin pelajaran selanjutnya. Sehingga jumlah siswa yang hadir tidak menentu, terutama pada kelas XI 5 dan XI 6 pada mata pelajaran pemeliharaan sistem kelistrikan kendaraan ringan. Hasil dari penelitian di dapatkan bahwa motivasi belajar sebesar 94,57\% dapat di artikan sebagian siswa memiliki motivasi belajar yang sangat tinggi pada mata pelajaran pemeliharaan sistem kelistrikan kendaraan ringan.

\section{PEMBAHASAN}

Secara umum hasil penelitian menunjukkan siswa yang memiliki motivasi berdasarkan minat sebesar 14,60\%, berdasarkan kemandirian sebesar 18,97\%, berdasarkan kemauan sebesar 15,92\%, berdasarkan nilai ulangan sebesar 20,26\%, berdasarkan kepercayaan diri 
dalam belajar 10,99\%, dan morivasi siswa berdasarkan orentasi pada hasil 19,26\%, Data di atas menunjukkan bahwa indikator mana yang memiliki peran dalam memotivasi siswa untuk melaksanakan pembelajaran yaitu indikator nilai ulangan sebesar 20,26\%. Besar motivasi belajar siswa pada mata pelajaran pemeliharaan sistem kelistrikan kendaraan ringan yaitu $94,57 \%$.

Hasil penelitian menunjukkan bahwa rata-rata persentasi dari indikator minat sebesar 84,63\%. Persentase dari tiap item dan rata-rata tiap item menunjukkan kiteria sangat tinggi. Siswa mempunyai minat belajar, kesukaan dan kehendak untuk mempelajari pelajaran pemeliharaan sistem kelistrikan kendaraan ringan sangat tinggi. Motivasi belajar berdasarkan minat merupakan keterlibatan diri yang disukainya, dikehendakinya pada sebuah aktivitas (Schunk and Zimmerman, 2008).

Rata-rata persentasi dari indikator kemandirian sebesar 65,94\%. Persentase dari tiap item dan rata-rata tiap item menunjukkan kiteria tinggi. Dapat dikatakan bahwa siswa memiliki kemandirian yang tinggi untuk belajar pada mata pelajaran pemeliharaan sistem kelistrikan kendaraan ringan. Motivasi belajar berdasarkan kemandirian merupakan sebagai proses belajar yang terjadi karena pengaruh dari pemikiran, perasaan, strategi, dan perilaku sendiri yang berorientasi pada pencapaian tujuan.

Rata-rata persentasi dari indikator kemauan sebesar 69,18\%. Persentase dari tiap item dan rata-rata tiap item menunjukkan kiteria tinggi. Kemauan siswa memiliki kemauan untuk mengatur diri, motivasi dan proses kognitif yang tinggi untuk belajar pada mata pelajaran pemeliharaan sistem kelistrikan kendaraan ringan. Motivasi belajar berdasarkan kemauan merupakan sebagai dari sebuah pengatur diri yang lebih besar yang mencangkup motivasi dan proses kognitif lainnya.

Rata-rata persentasi dari indikator Nilai ulangan sebesar 70,42\%. Persentase dari tiap item dan rata-rata tiap item menunjukkan kiteria tinggi. Nilai ulangan dan data yang ada bahwa siswa mempunyai kemauan yang tinggi untuk mendapatkan nilai ulangan yang tinggi pada mata pelajaran pemeliharaan sistem kelistrikan kendaraan ringan. Motivasi belajar berdasarkan nilai ulangan merupakan ikatan langsung dengan prilaku pencapaian kerja atau hasil.

Rata-rata persentasi dari indikator Kepercayaan diri sebesar 63,69\%. Persentase dari tiap item dan rata-rata tiap item menunjukkan kiteria tinggi. Sehingga dapat dikatakan bahwa siswa 
mempunyai kepercayaan diri yang tinggi untuk mempelajari mata pelajaran pemeliharaan sistem kelistrikan kendaraan ringan. Motivasi belajar berdasarkan kepercayaan diri dalam belajar merupakan peranan yang sangat penting dalam mempengaruhi usaha yang dilakukan, seberapa kuat usahanya dan memprediksi keberhasilan yang akan dicapai.

Rata-rata persentasi dari indikator Orentasi pada hasil sebesar $83,71 \%$. Persentase dari tiap item dan rata-rata tiap item menunjukkan kriteria sangat tinggi. Sehingga dapat dikatakan bahwa siswa merasa senang bila mana target atau nilai akademis untuk menyelesaikannggi mata pelajaran pemeliharaan sistem kelistrikan kendaraan ringan tercapai dengan baik. Motivasi belajar berdasarkan orentasi pada hasil merupakan kemampuan untuk mendapatkan nilai akademis yang baik (Fleisher, 2009).

\section{KESIMPULAN}

Kesimpulan penelitian ini, sebagai berikut: motivasi belajar siswa untuk melaksanakan pembelajaran pada mata pelajaran pemeliharaan sistem kelistrikan kendaraan ringan sangat tinggi. Hasil perhitungan persentase motivasi belajar, menunjukkan sebagian besar siswa memiliki motivasi yang tinggi untuk melaksanakan pembelajaran pada mata pelajaran pemeliharaan sistem kelistrikan kendaraan ringan.

\section{REFERENSI}

Fleisher, S. (2009). Book Review Motivation and Self-Regulated Learning: Theory, Research, and Applications. 1(3). California State University: Channel Islands-USA.

Santrock, J. W. (2011). Educational Psychology $5^{\text {th }}$ ed. New York: McGraw-Hill.

Schunk, D. H. \& Zimmerman, B. J. (2008). Motivation and Self Regulated Learning: Theory, Research, and Applications. New York: Lawrence Erlbaum Associates.

Schunk, D. H. et. al. (2012). Motivasi dalam Pendidikan: Teori, Penelitian, dan Aplikasi. Jakarta: PT. Indeks.

Uno, H. B. (2009). Teori Motivasi dan Pengukurannya: Analisis dibidang Pendidikan. Jakarta: Bumi Aksara. 